\title{
Indoor/Outdoor Air Quality Assessment at School near the Steel Plant in Taranto (Italy)
}

\author{
A. Di Gilio, ${ }^{1}$ G. Farella, ${ }^{1}$ A. Marzocca, ${ }^{2}$ R. Giua, ${ }^{2}$ G. Assennato, ${ }^{2}$ \\ M. Tutino, ${ }^{2}$ and G. de Gennaro ${ }^{1}$ \\ ${ }^{1}$ Biology Department, University of Bari “Aldo Moro”, Via Orabona 4, 70125 Bari, Italy \\ ${ }^{2}$ Apulia Region Environmental Protection Agency (ARPA Puglia), Corso Trieste 27, 70126 Bari, Italy \\ Correspondence should be addressed to A. Di Gilio; alessia.digilio@uniba.it
}

Received 9 January 2017; Accepted 20 February 2017; Published 22 May 2017

Academic Editor: Pedro Salvador

Copyright (C) 2017 A. Di Gilio et al. This is an open access article distributed under the Creative Commons Attribution License, which permits unrestricted use, distribution, and reproduction in any medium, provided the original work is properly cited.

\begin{abstract}
This study aims to investigate the air quality in primary school placed in district of Taranto (south of Italy), an area of high environmental risk because of closeness between large industrial complex and urban settlement. The chemical characterization of PM2.5 was performed to identify origin of pollutants detected inside school and the comparison between indoor and outdoor levels of PAHs and metals allowed evaluating intrusion of outdoor pollutants or the existence of specific indoor sources. The results showed that the indoor and outdoor levels of $\mathrm{PM} 2.5, \mathrm{BaP}, \mathrm{Cd}, \mathrm{Ni}, \mathrm{As}$, and $\mathrm{Pb}$ never exceeded the target values issued by World $\mathrm{Health}$ Organization (WHO). Nevertheless, high metals and PAHs concentrations were detected especially when school were downwind to the steel plant. The $I / O$ ratio showed the impact of outdoor pollutants, especially of industrial markers as $\mathrm{Fe}, \mathrm{Mn}, \mathrm{Zn}$, and $\mathrm{Pb}$, on indoor air quality. This result was confirmed by values of diagnostic ratio as $\mathrm{B}(\mathrm{a}) \mathrm{P} / \mathrm{B}(\mathrm{g}) \mathrm{P}, \mathrm{IP} /(\mathrm{IP}+\mathrm{BgP}), \mathrm{BaP} / \mathrm{Chry}$, and $\mathrm{BaP} /(\mathrm{BaP}$ + Chry), which showed range characteristics of coke and coal combustion. However, Ni and As showed I/O ratio of 2.5 and 1.4, respectively, suggesting the presence of indoor sources.
\end{abstract}

\section{Introduction}

Children spend most of day in indoor environments and especially in school classrooms [1]. Indoor air quality (IAQ) in schools has been identified as an important factor that can affect children health, because of a large exposure to indoor air pollutants in that environment.

Airborne particles in classroom have been recognized as the principal class of contaminants that can affect indoor air quality and students health $[2,3]$. Furthermore, these particles consist of several compounds such as mineral fibers, heavy metals, and toxic chemical substances which may pose health concerns to occupants [4]. Numerous epidemiological studies have pointed out that exposure to PM is correlated with a large variety of adverse acute and chronic health effects, including heart and respiratory diseases $[5,6]$. Those repercussions on health are even more adverse for children that have a respiratory system yet non-fully developed. The health effect of particles depends strongly on their size, specific surface area, number, and chemical composition. PM size is a key factor affecting the percentage of particle deposition in different parts of the respiratory system. Along with PM size, chemical components (including polycyclic aromatic hydrocarbons (PAHs), other organic carbons, elemental carbon, sulfate and nitrate salts, and metals) also affect the toxicity of PM [7]. Several studies have highlighted that PAHs and metals represent the two main PM classes correlated with the adverse health effects [8-10]. The PAHs bound to PM represent an increasing concern because of their carcinogenicity and mutagenicity [8]. Studies have shown that particle-bound metals are relevant in causing mitochondrial damage [11] and induction of oxidative stress [12], which ultimately leads to an increase in cardiovascular mortality and morbidity [13]. These potentially toxic elements may originate from various industrial or urban sources. The indoor PM concentration variability is determined by the activities that occur inside the building. However, outdoor air contaminants may intrude indoors by two ways: by means of 
opened windows or doors and by penetration through rifts in the building envelope [14].

Until now, only few studies have characterized the chemical composition of indoor particles and little is known regarding the school environment [4]. More studies on the PM concentrations and their composition in schools are essential to assess the exposure of children to airborne particles. Generally, the typical indoor PM sources, such as heating combustion, cooking, and smoking, are missing in school buildings. Nevertheless, classrooms are characterized by a complex environment that depends on several factors such as number of occupants, activities, ventilation system, outdoor PM concentration and composition, tightness, and furniture and materials of school building [15]. Besides, the site-specific characteristics of the investigated area play an important role in the indoor PM concentration when the school is located nearby an industrial area. Indeed, the PM is considered an outdoor pollutant that can be found in indoor environment by means of intrusion or in presence of discontinuous sources such as smoking of cigarettes, candles burning, chalks use, and resuspension [16].

The aim of the present study is to characterize IAQ in a primary school building located nearby the high-impact industrial sites such as the industrial area of Taranto (south of Italy).

The industrial area of Taranto is, in fact, considered one of the areas of high environmental risk and it is included in the list of polluted sites of national interest because of the presence of a large industrial complex near the urban settlement.

\section{Material and Methods}

2.1. PM Sampling Campaign. PM2.5 samples were collected inside the atrium of the school building located in a district of Taranto city, called Tamburi, few kilometres away from the biggest European steel plant. Taranto $\left(40^{\circ} 28^{\prime} \mathrm{N} 17^{\circ} 14^{\prime} \mathrm{E}\right)$ is the third most populated city of the Southern Italy and its industrial area includes the biggest steel plant in Europe, a refinery, a quarry, a cement plant, a composting plant, and military and trade harbors. Because of the proximity of this large industrial complex to the urban settlement (Tamburi district), Taranto is one of the areas identified at high environmental risk in Italy and it has been included in the list of the polluted sites of national interest (Figure 1).

Eleven daily samples of PM2.5 were collected from 11 to 22 December 2014 on quartz fiber filters (Whatman) using low-volume air sampler (Skypost by TRC TECORA) and FAI sampling heads operating to $2.3 \mathrm{~m}^{3} \mathrm{~h}^{-1}$. According to UNI EN 1234-1, the collected PM filters were conditioned for 48 hours in a climatic chamber provided with a control system for the temperature and the humidity $\left(20 \pm 1^{\circ} \mathrm{C}\right.$ and $50 \pm 5 \%$ RH) (Activa Climatic, Aquaria, Milan, Italy) and then, the particulate mass on the filter was measured by using an analytical balance (Sartorius Genius series, mod. SE2, Germany) with a sensitivity of $0.0001 \mathrm{mg}$.

Then, the PM filters ( $47 \mathrm{~mm}$ diameter) were cut in two parts: half of the filter was analysed in order to determinate

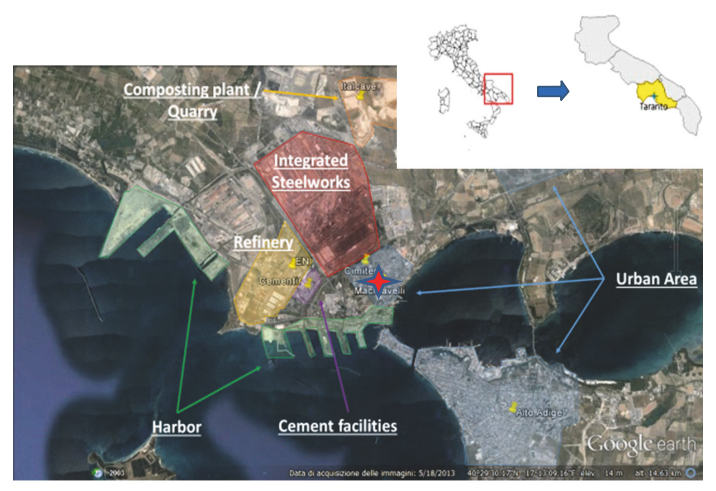

FIgURE 1: Map of Taranto (south of Italy). Red star shows sampling site.

elements ( $\mathrm{Al}, \mathrm{V}, \mathrm{Cr}, \mathrm{Fe}, \mathrm{Mn}, \mathrm{Co}, \mathrm{Ni}, \mathrm{Cu}, \mathrm{Zn}, \mathrm{As}, \mathrm{Cd}$, and $\mathrm{Pb})$ and the other half was analysed for PAHs determination (Benzo[a]anthracene $(\mathrm{BaA})$, benzo $[\mathrm{b}+\mathrm{j}]$ fluoranthene $(\mathrm{BbF})$, benzo[k]fluoranthene $(\mathrm{BkF})$, benzo[a]pyrene $(\mathrm{BaP})$, indeno[1,2,3-cd]pyrene (IP), benzo[ghi]perylene (BgP), and dibenzo[a,h]anthracene (DBA)).

Simultaneously, real-time monitoring of total PAHs was carried out by means Ecochem PAS monitor (Saras S.p.A.) in order to study the activation of sources during the monitored days. This monitor, using an Excimer lamp at a determined wavelength, ionizes only the carbon aerosols, while gas molecules and noncarbon aerosols remain neutral. The positively charged particles are collected on a filter inside an electrometer, where the charge measured is proportional to the concentration of total PAH. Indoor/outdoor $(I / O)$ comparisons, useful to evaluate the different $I / O$ contributions and to study the intrusion phenomena, were guaranteed by proximity between the selected school and the regional air quality station called Machiavelli, on the same street and 200 meters ahead with respect the investigated school. Only data about European regulated pollutants as $\mathrm{PM}, \mathrm{BaP}, \mathrm{Ni}$, $\mathrm{Cd}, \mathrm{Pb}$, and $\mathrm{As}$, about total $\mathrm{PAHs}$ monitored in addition to meteorological data, were obtained for Machiavelli station by regional air quality network.

\subsection{Chemical Characterization of PM2.5. Half of PM2.5} filters were extracted with a mixture of acetone/hexane by means of a microwave assisted solvent extraction (Milestone, model Ethos D). The extracted samples were analysed using an Agilent 6890 PLUS gas chromatograph (Agilent Technologies, Inc., Santa Clara, CA, USA) equipped with a programmable temperature vaporization injection system (PTV) and interfaced to a mass spectrometer, operating in electron impact ionization (Agilent MS$5973 \mathrm{~N})$. Benzo[a] anthracene (BaA), benzo[b+j]fluoranthene $(\mathrm{BbF})$, benzo[k]fluoranthene $(\mathrm{BkF})$, benzo[a]pyrene $(\mathrm{BaP})$, indeno[1,2,3-cd]pyrene (IP), benzo[ghi]perylene (BgP), and dibenzo[a,h]anthracene (DBA) were determined using the signals corresponding to the molecular ions: $\mathrm{BaA}(228), \mathrm{BbF}$ (252), BkF (252), BaP (252), IP (276), BgP (276), and DbA (278). Perylene-D12 (PrD, 264) was used as internal standard (IS). The analytical performances (extraction recovery, 
TABLE 1: Mean, minimum, and maximum concentration of PM2.5 $\left(\mu \mathrm{g} / \mathrm{m}^{3}\right)$, PAHs, and metals $\left(\mathrm{ng} / \mathrm{m}^{3}\right)$ measured inside the investigated school.

\begin{tabular}{|c|c|c|c|c|c|}
\hline $\begin{array}{l}\text { Mean } \\
(\min -\max ) \\
\mathrm{ng} / \mathrm{m}^{3}\end{array}$ & This study & Viana et al., 2014 [28] & Zwoździak et al., 2013 [23] & Hassanvand et al., 2015 [24] & Oliveira et al., 2017 [30] \\
\hline Location & Taranto, Italy & Barcelona, Spain & Wroclaw, Poland & Tehran, Iran & Oporto, Portugal \\
\hline $\mathrm{BaA}$ & $0.15(0.11-0.23)$ & & & 24.5 & $0.046(0.041-0.051)$ \\
\hline $\mathrm{Cr}$ & $0.21(0.17-0.28)$ & & & 39.26 & $0.13(0.11-0.15)$ \\
\hline $\mathrm{BbF}$ & $0.51(0.33-0.71)$ & & & 23.75 & $0.7(0.59-0.83)$ \\
\hline $\mathrm{BkF}$ & $0.29(0.20-0.39)$ & & & 12.22 & $0.12(0.10-0.15)$ \\
\hline $\mathrm{BaP}$ & $0.22(0.14-0.32)$ & & & 5.42 & $0.27(0.21-0.33)$ \\
\hline IP & $0.34(0.24-0.52)$ & & & 2.23 & $0.44(0.36-0.52)$ \\
\hline DBA & $0.25(0.18-0.34)$ & & & 13.75 & $1.5(1.3-1.8)$ \\
\hline $\mathrm{BgP}$ & $0.42(0.24-0.68)$ & & & 10.43 & $0.61(0.51-0.74)$ \\
\hline $\mathrm{Al}$ & $635.3(521.8-703.2)$ & & 561 & 39.72 & \\
\hline $\mathrm{V}$ & $1.17(0.81-1.92)$ & 3.4 & & & \\
\hline $\mathrm{Cr}$ & $14.5(11.9-19.6)$ & 3.1 & 6.06 & 5.55 & \\
\hline $\mathrm{Fe}$ & $212(93.9-693)$ & 200 & 525 & 102.20 & \\
\hline $\mathrm{Mn}$ & $4.93(2.36-8.58)$ & 5.9 & 46 & 15.25 & \\
\hline Co & $0.18(0.13-0.25)$ & & & & \\
\hline $\mathrm{Ni}$ & $5.24(3.20-10.6)$ & 2.3 & 2.04 & 4.66 & \\
\hline $\mathrm{Cu}$ & $13.9(6.7-26.8)$ & 9.1 & 50 & 22.17 & \\
\hline $\mathrm{Zn}$ & $15.5(5.20-30.5)$ & 42.1 & 267 & 68.90 & \\
\hline As & $0.64(0.42-0.81)$ & 0.34 & 4 & 3.01 & \\
\hline $\mathrm{Cd}$ & $0.09(0.05-0.15)$ & 0.69 & & 0.29 & \\
\hline $\mathrm{Pb}$ & $3.81(1.65-10.6)$ & 3.73 & 85 & 60.60 & \\
\hline $\begin{array}{l}\text { PM2.5 } \\
\left(\mu \mathrm{g} / \mathrm{m}^{3}\right)\end{array}$ & $16.6(10.6-27.1)$ & 29.9 & $59.8(18.2-86.6)$ & $20(3-81)$ & $25.8(9.2-66.6)$ \\
\hline
\end{tabular}

extraction linearity, analytical repeatability, and LOD) were verified in our previous work [17].

In addition, the other half of PM2.5 samples were digested in $8 \mathrm{ml}$ of nitric acid and $2 \mathrm{ml}$ of hydrogen peroxide solution by using a microwave system (Milestone mod. Ethos D). The extract was analysed by Inductively Coupled Plasma Mass Spectrometry (ICP-MS, Perkin Elmer NexION 350) in order to determine $\mathrm{Al}, \mathrm{V}, \mathrm{Cr}, \mathrm{Fe}, \mathrm{Mn}, \mathrm{Co}, \mathrm{Ni}, \mathrm{Cu}, \mathrm{Zn}, \mathrm{As}, \mathrm{Cd}$, and $\mathrm{Pb}$ using $\mathrm{Rh}$ as internal standard. Recoveries varied from $91.4 \pm$ $2.8 \%$ to $95.8 \pm 1.1 \%$, for all investigated metals. Limits of detection (LODs) ranged from $0.02 \mathrm{ng} / \mathrm{m}^{3}$ for $\mathrm{Cd}$ to $0.27 \mathrm{ng} / \mathrm{m}^{3}$ for $\mathrm{Pb}$. Standards were analysed daily, as well as filter blank, every 5 samples to verify instrumental performance. Each quantification was performed in triplicate.

\section{Results and Discussion}

3.1. PM Mass Concentrations. The basic statistics (mean, maximum, and minimum) of mass and chemical composition of PM2.5 determined for the investigated period and school are summarized in Table 1.

During the investigated period, no significant differences can be observed for PM2.5 concentrations determined inside and outside the school. The mean PM2.5 concentrations were 16.6 and $15.9 \mu \mathrm{g} / \mathrm{m}^{3}$ for indoor and outdoor environments, respectively. These values were lower than the European target settled $\left(25 \mu \mathrm{g} / \mathrm{m}^{3}\right)$ and comparable to those obtained in other regions of the world (e.g., between 10.7 and $14.8 \mu \mathrm{g} / \mathrm{m}^{3}$ in three schools in Quito, Ecuador [1]; between $12 \pm 2.3$ and $24.7 \pm 16 \mu \mathrm{g} / \mathrm{m}^{3}$ in Italian classroom [18]; between 2.8 and $13.9 \mu \mathrm{g} / \mathrm{m}^{3}$ in Swedish schools [19]). Moreover the values determined in this study were lower than those found inside classrooms located in centre of European metropolis in London $\left(30 \mu \mathrm{g} / \mathrm{m}^{3},[20]\right)$; Athens $\left(82 \pm 56 \mu \mathrm{g} / \mathrm{m}^{3},[16]\right)$; Barcelona $\left(8.3-95 \mu \mathrm{g} / \mathrm{m}^{3},[21]\right)$; Munich $\left(19.3-105.9 \mu \mathrm{g} / \mathrm{m}^{3},[4]\right)$; Antwerp (11-166 $\mu \mathrm{g} / \mathrm{m}^{3}$, [22]); and Wroclaw (44-143 $\mu \mathrm{g} / \mathrm{m}^{3}$, [23]).

The mean $I / O$ ratio was $1.08 \pm 0.37$; thus, PM levels slightly higher were found inside the school suggesting a contribution of indoor sources to PM2.5 components. Moreover, the indoor/outdoor correlation for PM2.5 (Figure 2) showed a zero coefficient of determination $\left(R^{2}\right)$ for the collected data. The flat slopes $(0.21)$ was due to the high intercepts obtained (13.25) that it indicated a contribution of indoor sources to PM2.5 [21]. This finding could be attributed to extreme physical activity leading to the resuspension of coarse particles in the school. 


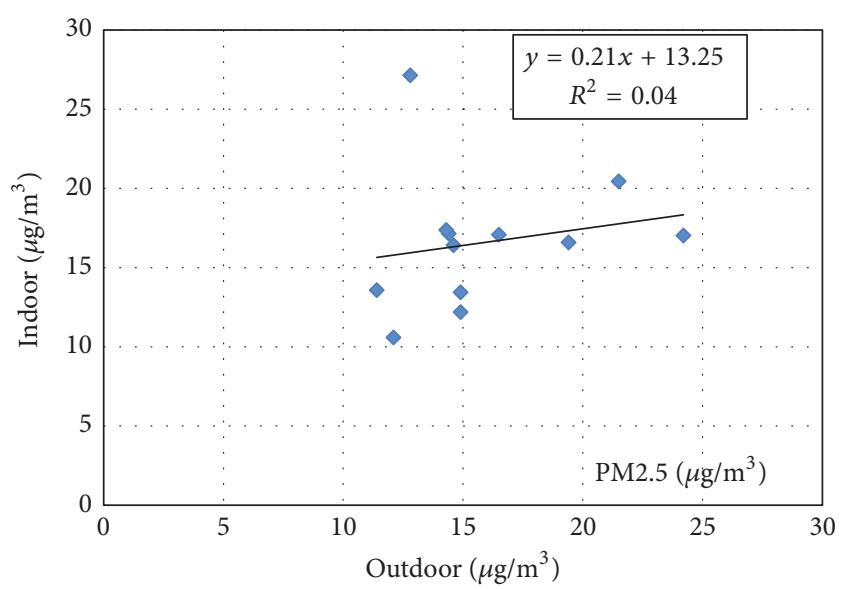

FIGURE 2: Scatterplot showing the indoor/outdoor correlation for PM2.5.

\subsection{Chemical Characterization of $P M$}

3.2.1. Metals. The mean levels of metals measured in indoor PM2.5 samples during sampling campaign are summarized in Table 1. The most abundant metals detected were $\mathrm{Al}$ $\left(521.8-703.2 \mathrm{ng} / \mathrm{m}^{3}\right)$ and $\mathrm{Fe}\left(93.9-693.5 \mathrm{ng} / \mathrm{m}^{3}\right)$. These values were comparable with those determined in a secondary school located in the centre of Wroclaw, Poland [23], but higher than those measured inside schools at Tehran [24]. Several studies have reported that the presence of $\mathrm{Fe}$ and $\mathrm{Al}$ in $\mathrm{PM}$ is due mainly to road dust resuspension and also to industrial sources $[25,26]$. In fact, during the sampling campaign the indoor levels of metallurgical industry markers as $\mathrm{Fe}, \mathrm{Mn}, \mathrm{Cd}, \mathrm{As}$, and $\mathrm{Zn}$ reached their maximum values $\left(693,8.6,0.15,0.81\right.$, and $30.5 \mathrm{ng} / \mathrm{m}^{3}$, resp.) on 18 and 21 December, when strong wind blew from north-northwest transporting air pollutants from the nearby steel plant to the investigated school. Fe and $\mathrm{Mn}$ are related to park mineral dusting or blast furnace charging, $\mathrm{Cd}$ and $\mathrm{Zn}$ are emitted by sintering processes, and, finally, As is released by mining and smelting of base metals or fuel combustion [27].

The concentrations of $\mathrm{Pb}$ determined in this study were comparable to those measured in Spain [27] and lower than those found in Poland and Tehran [23, 24]. Although $\mathrm{Pb}$ has been found to be usually emitted from sources such as fuel and motor oil combustion, in the developed world the use of leaded gasoline decreased since 1990s due to national regulations, determining a drastic reduction of $\mathrm{Pb}$ levels in atmosphere. Therefore, the indoor and outdoor concentrations of lead determined in this work $\left(1.65-10.6 \mathrm{ng} / \mathrm{m}^{3}\right.$ for indoor and $3.3-37 \mathrm{ng} / \mathrm{m}^{3}$ for outdoor) were lower than the annual national ambient air quality standards $\left(500 \mathrm{ng} / \mathrm{m}^{3}\right)$. However, considering the trend of $\mathrm{Pb}$ concentrations like that of industrial markers, and maximum values of $\mathrm{Pb}$ concentration registered in correspondence of N-W wind direction, an industrial source could be hypothesized for $\mathrm{Pb}$. It could be probably involved in sintering processes [24].

In addition to lead, also $\mathrm{Ni}, \mathrm{Cd}$, and As, classified by the IARC as carcinogenic to humans (Group 1), never exceeded standard annual outdoor levels $\left(20,6\right.$, and $5 \mathrm{ng} / \mathrm{m}^{3}$, resp.) settled by European Commission (EC) [28]. However, Ni and As, unlike the other metals, showed $I / O$ ratio higher than 1 (2.5 and 1.4 in average, resp.) suggesting the existence of some indoor sources. School equipment made from treated wood or paints and dyes used for Christmas gifts hand-made by children inside school could be probably the indoor sources of these pollutants [23].

Although $\mathrm{V}$ concentrations resulted lower than those measured in Spanish schools [27], the highest values were determined on 13 and 19 December 2014, when wind blowing from west-southwest probably allowed the transport of this pollutants from refinery to the investigated school.

Finally, Cr levels resulted up to 5 times greater than those obtained in other works (Table 1), probably due to a joint effect of two sources: industrial and traffic ones. In fact, $\mathrm{Cr}$ is emitted from road traffic and it mainly derives from both break wear $[29,30]$. However, metallurgic industry has been also identified as anthropogenic source of $\mathrm{Cr}$ [24].

3.2.2. PAHs. Among individual PAHs bound to PM, benz[a]anthracene, chrysene, benzo[b]fluoranthene, benzo[j]fluoranthene, benzo[k]luoranthene, benzo[a]pyrene, dibenz[a,h]anthracene, and indeno[1,2,3-cd]pyrene were designated by International Agency Research on Cancer as possible or probable carcinogens (IARC, 2002, 2010) and were analysed in this work. The levels of these carcinogenic PAHs (i.e., $\Sigma$ PAHs) at the indoor air of the studied school ranged from 1.51 and $2.36 \mathrm{ng} / \mathrm{m}^{3}$ accounting for $14.3 \%$ of PM2.5 concentration. The indoor concentrations of the eight carcinogenic PAHs, that is, $\mathrm{BaA}, \mathrm{Chr}, \mathrm{BbF}, \mathrm{BkF}, \mathrm{BaP}$, $\mathrm{BgP}, \mathrm{DBA}$, and IP, were similar to those found in a primary school of Portugal [28] and up to two orders of magnitude lower than the values determined in Tehran [22]. The most abundant indoor PAHs bound to PM2.5 were BbF, BgP, IP, $\mathrm{BkF}$, and DBA, accounting for about $22 \%, 18 \%, 14 \%, 12 \%$, and $10 \%$ of the total PAHs concentration, respectively. High abundances of DBA and $\mathrm{BgP}$ highlight vehicular traffic source (light-duty gasoline) while $\mathrm{BbF}$ and IP abundances suggest emissions from coke oven [31-33]. In fact, according to trend of $\mathrm{Fe}, \mathrm{Mn}, \mathrm{Zn}$, and $\mathrm{Pb}$ concentrations, $\mathrm{PAHs}$ showed the highest values in correspondence of wind blowing from industrial area to the investigated school.

As concerns benzo[a]pyrene, indicator of carcinogenic PAHs, the current European legislation on ambient air (Directive 2004/107/EC, 2005) sets annual target value of $1 \mathrm{ng}$ $\mathrm{m}^{-3}$ for carcinogenic PAHs in PM10. The mean concentration of this pollutant during the sampling period was $0.22 \pm$ $0.07 \mathrm{ng} \mathrm{m}^{-3}$ and $0.32 \pm 0.13 \mathrm{ng} \mathrm{m}^{-3}$ in indoor and outdoor environments, respectively; and they never exceeded the target value.

One of the most important aspects of the air quality management process is the identification of the source of pollutants. Indoor-to-outdoor $(I / O)$ concentration ratios of individual PAHs provide a rough identification of the pollution origin. The PAH concentrations in outdoor and indoor air determined in this work were not statistically different and the mean $I / O$ ratio for $\mathrm{BaP}$ was $0.82 \pm 0.38$, indicating outdoor 
TABLE 2: DRs range determined in literature and in this study.

\begin{tabular}{|c|c|c|c|c|}
\hline & BaP/Chry & $\mathrm{B}(\mathrm{a}) \mathrm{P} / \mathrm{B}(\mathrm{g}) \mathrm{P}$ & $\mathrm{IP} /(\mathrm{IP}+\mathrm{BgP})$ & $\mathrm{BaA} /(\mathrm{BaA}+\mathrm{Chry})$ \\
\hline Traffic $[34,35]$ & & $0.5-0.6$ & $0.17[35]$ & \\
\hline Diesel emissions & & $0.45-0.83$ & & \\
\hline Gasoline cars & & $0.30-0.40$ & $0.21-0.22[33,40-43]$ & $0.76[33,45]$ \\
\hline $\begin{array}{l}\text { Lead smelter } \\
\text { (coke burning) }\end{array}$ & & $0.45[36]$ & $0.36[36,38]$ & \\
\hline Coke combustion & $>0.35[33,45]$ & $\geq 1.25[33,37]$ & 0.33 [39] & \\
\hline Coal burning & & $0.9-6.6[38,39]$ & $0.56[34,38]$ & $0.27-0.65[33,45]$ \\
\hline Wood combustion & & & 0.62 & $0.43[33,45]$ \\
\hline $\begin{array}{l}\text { This study's } \\
\text { mean (min-mx) }\end{array}$ & $\begin{array}{c}1.06 \\
(0.76-1.32)\end{array}$ & $\begin{array}{c}0.64 \\
(0.30-1.35)\end{array}$ & $\begin{array}{c}0.45 \\
(0.31-0.55)\end{array}$ & $\begin{array}{c}0.41 \\
(0.37-0.52)\end{array}$ \\
\hline $\begin{array}{l}\text { Taranto, } \\
\text { outdoor [31] }\end{array}$ & & $\begin{array}{c}0.77 \\
(0.27-1.55)\end{array}$ & $\begin{array}{c}0.47 \\
(0.29-0.56)\end{array}$ & \\
\hline
\end{tabular}

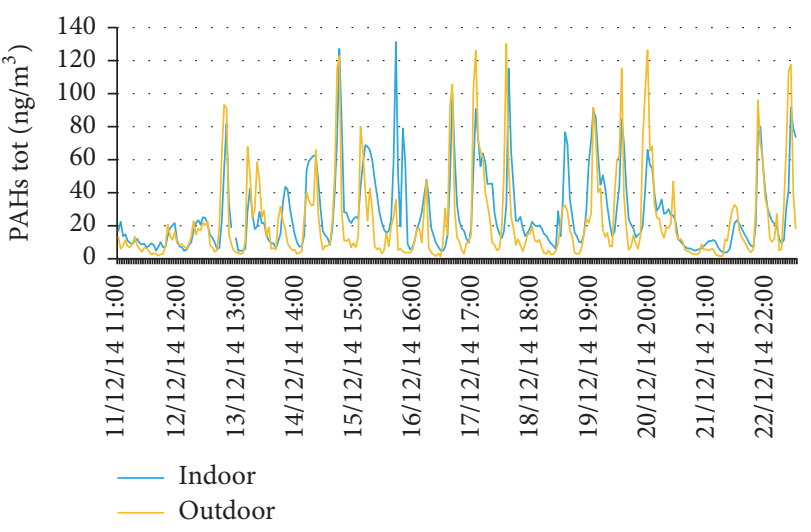

FIGURE 3: Trend of real-time PAHs concentrations monitored inside and outside the investigated school.

origin of these contaminants. This finding was confirmed by real-time monitoring of total PAHs. In fact, as shown in Figure 3, concentrations and trends of total PAHs monitored inside and outside the school were comparable except for some morning hours on 15-16 December 2014, when higher indoor concentrations were detected. In the same days, the $\mathrm{BaP} I / O$ ratio also reached its maximum value (ranging from 1.2 to 1.4), suggesting potential contribution of indoor sources. Probably, the use of artistic materials as wax melting to prepare Christmas gifts hand-made or the burning candles during preparative Christmas show contribute to high indoor concentration of PAHs [34].

In addition, analysis of diagnostic ratios of individual $\mathrm{PAH}$ congeners can provide further insight regarding PAHs origin. In fact, because of different sources show specific concentration profiles of PAHs, several studies focused on $\mathrm{PAHs}$ diagnostic ratios, especially on $\mathrm{B}(\mathrm{a}) \mathrm{P} / \mathrm{B}(\mathrm{g}) \mathrm{P}$ and $\mathrm{IP} /(\mathrm{IP}$ $+\mathrm{BgP})$ ratios [34-46]. The value of $\mathrm{B}(\mathrm{a}) \mathrm{P} / \mathrm{B}(\mathrm{g}) \mathrm{P}, \mathrm{IP} /(\mathrm{IP}+$ $\mathrm{BgP}), \mathrm{BaP} / \mathrm{Chry}$, and $\mathrm{BaA} /(\mathrm{BaA}+\mathrm{Chry})$ ratio inside the investigated school ranged from 0.30 to 1.35 , from 0.31 to 0.55 , from 0.76 to 1.32 , and from 0.37 to 0.52 , respectively (Table 2 ). These results were comparable with those determined in
Taranto industrial area for outdoor [31] and, except for $\mathrm{B}(\mathrm{a}) \mathrm{P} / \mathrm{B}(\mathrm{g}) \mathrm{P}$ ratio, showed the strong impact of industrial area and especially of steel plant on indoor and outdoor air quality in Taranto. However, even if lower mean values were determined for $\mathrm{B}(\mathrm{a}) \mathrm{P} / \mathrm{B}(\mathrm{g}) \mathrm{P}$ ratio, the analysis of these depending on the wind direction showed that the highest values of $\mathrm{B}(\mathrm{a}) \mathrm{P} / \mathrm{B}(\mathrm{g}) \mathrm{P}$ ratio ranging from 1.18 to 1.35 , typical of coke combustion, were determined when winds blew mainly from the NW sector. On the contrary, these DR values decreased to $0.5-0.6$, typical of vehicular traffic contribution, when the schools located near the steel plant were upwind of industrial area.

\section{Conclusions}

The main goal of this work was to assess the impact of the biggest European steel plant on nearby residential area of Taranto (South of Italy) and, in particular, on indoor air quality inside school. Therefore, a PM2.5 sampling campaign was carried out from December 11 to 22,2014 , in a primary school located in Tamburi district of Taranto. The chemical characterization of PM provided PAH and metal concentrations. In addition, real-time total PAHs were monitored inside and outside the investigated school. The results showed that the indoor and outdoor levels of PM2.5, BaP, Cd, Ni, As, and $\mathrm{Pb}$ were lower than guidelines issued by World Health Organization (WHO). Nevertheless, high metals and PAHs concentrations were detected especially when schools were downwind to the steel plant. The $I / O$ ratio showed the impact of outdoor pollutants, especially of industrial markers as $\mathrm{Fe}, \mathrm{Mn}, \mathrm{Zn}$, and $\mathrm{Pb}$, on indoor air quality. This result was confirmed by diagnostic ratio as $\mathrm{B}(\mathrm{a}) \mathrm{P} / \mathrm{B}(\mathrm{g}) \mathrm{P}, \mathrm{IP} /(\mathrm{IP}+$ $\mathrm{BgP}), \mathrm{BaP} / \mathrm{Chry}$, and $\mathrm{BaP} /(\mathrm{BaP}+\mathrm{Chry})$, which showed range values typical of coke and coal combustion. However, $\mathrm{Ni}$ and As showed $I / O$ ratio of 2.5 and 1.4 , respectively, suggesting the presence of indoor sources. These results could be probably due to the use of school equipment made from treated wood or paints and dyes for the Christmas gifts hand-made by children. 


\section{Disclosure}

This manuscript is based on a paper presented to TECH-AIR 2016 conference.

\section{Conflicts of Interest}

The authors declare that there are no conflicts of interest regarding the publication of this paper.

\section{Acknowledgments}

Special appreciation goes to ARPA Puglia, especially to Dr. Dambruoso Paolo Rosario and Dr. Placentino Claudia Marcella for the collaboration in sampling campaign.

\section{References}

[1] A. U. Raysoni, T. H. Stock, J. A. Sarnat et al., "Characterization of traffic-related air pollutant metrics at four schools in El Paso, Texas, USA: implications for exposure assessment and siting schools in urban areas," Atmospheric Environment, vol. 80, pp. 140-151, 2013.

[2] G. de Gennaro, P. R. Dambruoso, A. D. Loiotile et al., "Indoor air quality in schools," Environmental Chemistry Letters, vol. 12, no. 4, pp. 467-482, 2014.

[3] P. R. Dambruoso, G. de Gennaro, A. D. Loiotile et al., "School air quality: pollutants, monitoring and toxicity," in Pollutant Diseases, Remediation and Recycling, vol. 4 of Environmental Chemistry for a Sustainable World, pp. 1-44, Springer International Publishing, New York, NY, USA, 2013.

[4] H. Fromme, J. Diemer, S. Dietrich et al., "Chemical and morphological properties of particulate matter (PM10, PM2.5) in school classrooms and outdoor air," Atmospheric Environment, vol. 42, no. 27, pp. 6597-6605, 2008.

[5] C. A. Pope III and D. W. Dockery, "Health effects of fine particulate air pollution: lines that connect," Journal of the Air and Waste Management Association, vol. 56, no. 6, pp. 709-742, 2006.

[6] M. J. Nieuwenhuijsen, P. Dadvand, J. Grellier, D. Martinez, and M. Vrijheid, "Environmental risk factors of pregnancy outcomes: a summary of recent meta-analyses of epidemiological studies," Environmental Health, vol. 12, article 6, 2013.

[7] M. L. Bell, "Assessment of the health impacts of particulate matter characteristics," Research Reports: Health Effects Institute, no. 161, pp. 5-38, 2012.

[8] K.-H. Kim, S. A. Jahan, E. Kabir, and R. J. C. Brown, "A review of airborne polycyclic aromatic hydrocarbons (PAHs) and their human health effects," Environment International, vol. 60, pp. 71-80, 2013.

[9] P. Møller, P. H. Danielsen, D. G. Karottki et al., "Oxidative stress and inflammation generated DNA damage by exposure to air pollution particles," Mutation Research-Reviews in Mutation Research, vol. 762, pp. 133-166, 2014.

[10] S. Philip, R. V. Martin, A. Van Donkelaar et al., "Global chemical composition of ambient fine particulate matter for exposure assessment," Environmental Science and Technology, vol. 48, no. 22, pp. 13060-13068, 2014.

[11] N. Li, C. Sioutas, A. Cho et al., "Ultrafine particulate pollutants induce oxidative stress and mitochondrial damage," Environmental Health Perspectives, vol. 111, no. 4, pp. 455-460, 2003.
[12] A. E. Nel, D. Diaz-Sanchez, and N. Li, "The role of particulate pollutants in pulmonary inflammation and asthma: evidence for the involvement of organic chemicals and oxidative stress," Current Opinion in Pulmonary Medicine, vol. 7, no. 1, pp. 20-26, 2001.

[13] J. A. Araujo and A. E. Nel, "Particulate matter and atherosclerosis: role of particle size, composition and oxidative stress," Particle and Fibre Toxicology, vol. 6, article 24, 2009.

[14] C. Chen and B. Zhao, "Review of relationship between indoor and outdoor particles: I/O ratio, infiltration factor and penetration factor," Atmospheric Environment, vol. 45, no. 2, pp. 275288, 2011.

[15] P. Wolkoff, C. K. Wilkins, P. A. Clausen, and G. D. Nielsen, "Organic compounds in office environments-Sensory irritation, odor, measurements and the role of reactive chemistry," Indoor Air, vol. 16, no. 1, pp. 7-19, 2006.

[16] E. Diapouli, A. Chaloulakou, N. Mihalopoulos, and N. Spyrellis, "Indoor and outdoor PM mass and number concentrations at schools in the Athens area," Environmental Monitoring and Assessment, vol. 136, no. 1-3, pp. 13-20, 2008.

[17] P. Bruno, M. Caselli, G. de Gennaro, and M. Tutino, "Determination of polycyclic aromatic hydrocarbons (PAHs) in particulate matter collected with low volume samplers," Talanta, vol. 72, no. 4, pp. 1357-1361, 2007.

[18] F. C. Fuoco, L. Stabile, G. Buonanno et al., "Indoor air quality in naturally ventilated Italian classrooms," Atmosphere, vol. 6, no. 11, pp. 1652-1675, 2015.

[19] J. Wichmann, T. Lind, M. A.-M. Nilsson, and T. Bellander, "PM2.5, soot and NO2 indoor-outdoor relationships at homes, pre-schools and schools in Stockholm, Sweden," Atmospheric Environment, vol. 44, no. 36, pp. 4536-4544, 2010.

[20] A. J. Wheeler, I. Williams, R. A. Beaumont, and R. S. Hamilton, "Characterisation of particulate matter sampled during a study of children's personal exposure to airborne particulate matter in a UK urban environment," Environmental Monitoring and Assessment, vol. 65, no. 1, pp. 69-77, 2000.

[21] I. Rivas, M. Viana, T. Moreno et al., "Outdoor infiltration and indoor contribution of UFP and BC, OC, secondary inorganic ions and metals in PM2.5 in schools," Atmospheric Environment, vol. 106, pp. 129-138, 2015.

[22] M. Stranger, S. S. Potgieter-Vermaak, and R. Van Grieken, "Characterization of indoor air quality in primary schools in Antwerp, Belgium," Indoor Air, vol. 18, no. 6, pp. 454-463, 2008.

[23] A. Zwoździak, I. Sówka, B. Krupińska, J. Zwoździak, and A. Nych, "Infiltration or indoor sources as determinants of the elemental composition of particulate matter inside a school in Wrocław, Poland?" Building and Environment, vol. 66, pp. 173180, 2013.

[24] M. S. Hassanvand, K. Naddafi, S. Faridi et al., "Characterization of PAHs and metals in indoor/outdoor $\mathrm{PM}_{10} / \mathrm{PM}_{2.5} / \mathrm{PM}_{1}$ in a retirement home and a school dormitory," Science of the Total Environment, vol. 527-528, pp. 100-110, 2015.

[25] V. Celo and E. Dabek-Zlotorzynska, "Concentration and source origin of trace metals in $\mathrm{PM}_{2.5}$ collected at selected canadian sites within the canadian national air pollution surveillance program," in Urban Airborne Particulate Matter, Environmental Science and Engineering, pp. 19-38, Springer, Berlin, Heidelberg, Germany, 2011.

[26] S. Hasheminassab, N. Daher, A. Saffari, D. Wang, B. D. Ostro, and C. Sioutas, "Spatial and temporal variability of sources of 
ambient fine particular matter $\left(\mathrm{PM}_{2.5}\right)$ in California," Atmospheric Chemistry and Physics Discussions, vol. 14, no. 14, pp. 20045-20081, 2014.

[27] IARC, A Review of Human Carcinogens. Part C: Arsenic, Metals, Fibres, and Dusts. IARC Working Group on The Evaluation of Carcinogenic Risks to Humans, International Agency for Research on Cancer (IARC), Lyon, France, 2009.

[28] M. Viana, I. Rivas, X. Querol et al., "Indoor/outdoor relationships and mass closure of quasi-ultrafine, accumulation and coarse particles in Barcelona schools," Atmospheric Chemistry and Physics, vol. 14, no. 9, pp. 4459-4472, 2014.

[29] J. Sternbeck, Å. Sjödin, and K. Andréasson, "Metal emissions from road traffic and the influence of resuspension-results from two tunnel studies," Atmospheric Environment, vol. 36, no. 30, pp. 4735-4744, 2002.

[30] C. L. S. Wiseman, F. Zereini, and W. Püttmann, “Traffic-related trace element fate and uptake by plants cultivated in roadside soils in Toronto, Canada," Science of the Total Environment, vol. 442, pp. 86-95, 2013.

[31] A. Di Gilio, G. Ventrella, P. Giungato et al., "An intensive monitoring campaign of PAHs for assessing the impact of a steel plant," Chemosphere, vol. 168, pp. 171-182, 2017.

[32] M. Amodio, G. De Gennaro, A. Di Gilio, and M. Tutino, "Monitoring of the deposition of PAHs and metals produced by a steel plant in Taranto (Italy)," Advances in Meteorology, vol. 2014, Article ID 598301, 10 pages, 2014.

[33] K. Ravindra, R. Sokhi, and R. Van Grieken, "Atmospheric polycyclic aromatic hydrocarbons: source attribution, emission factors and regulation," Atmospheric Environment, vol. 42, no. 13, pp. 2895-2921, 2008.

[34] M. Oliveira, K. Slezakova, J. Madureira et al., "Polycyclic aromatic hydrocarbons in primary school environments: levels and potential risks," Science of The Total Environment, vol. 575, pp. 1156-1167, 2017.

[35] K. Ravindra, L. Bencs, E. Wauters et al., "Seasonal and sitespecific variation in vapour and aerosol phase PAHs over Flanders (Belgium) and their relation with anthropogenic activities," Atmospheric Environment, vol. 40, no. 4, pp. 771-785, 2006.

[36] S. S. Park, Y. J. Kim, and C. H. Kang, "Atmospheric polycyclic aromatic hydrocarbons in Seoul, Korea," Atmospheric Environment, vol. 36, no. 17, pp. 2917-2924, 2002.

[37] E. Manoli, A. Kouras, and C. Samara, "Profile analysis of ambient and source emitted particle-bound polycyclic aromatic hydrocarbons from three sites in northern Greece," Chemosphere, vol. 56, no. 9, pp. 867-878, 2004.

[38] B. Barletta, S. Meinardi, F. S. Rowland et al., "Volatile organic compounds in 43 Chinese cities," Atmospheric Environment, vol. 39, no. 32, pp. 5979-5990, 2005.

[39] S. Kong, J. Shi, B. Lu et al., "Characterization of PAHs within $\mathrm{PM}_{10}$ fraction for ashes from coke production, iron smelt, heating station and power plant stacks in Liaoning Province, China," Atmospheric Environment, vol. 45, no. 23, pp. 3777-3785, 2011.

[40] M. Akyüz and H. Çabuk, "Particle-associated polycyclic aromatic hydrocarbons in the atmospheric environment of Zonguldak, Turkey,' Science of the Total Environment, vol. 405, no. 1-3, pp. 62-70, 2008.

[41] A. Gogou, N. Stratigakis, M. Kanakidou, and E. G. Stephanou, "Organic aerosols in Eastern Mediterranean: components source reconciliation by using molecular markers and atmospheric back trajectories," Organic Geochemistry, vol. 25, no. 1-2, pp. 79-96, 1996.
[42] C. A. Pio, C. A. Alves, and A. C. Duarte, "Identification, abundance and origin of atmospheric organic particulate matter in a Portuguese rural area," Atmospheric Environment, vol. 35, no. 8, pp. 1365-1375, 2001.

[43] I. G. Kavouras, P. Koutrakis, M. Tsapakis et al., "Source apportionment of urban particulate aliphatic and polynuclear aromatic hydrocarbons (PAHs) using multivariate methods," Environmental Science and Technology, vol. 35, no. 11, pp. 2288-2294, 2001.

[44] G. Grimmer, J. Jacob, K.-W. Naujack, and G. Dettbarn, "Determination of polycyclic aromatic compounds emitted from brown-coal-fired residential stoves by gas chromatography/mass spectrometry," Analytical Chemistry, vol. 55, no. 6, pp. 892-900, 1983.

[45] E. Krugly, D. Martuzevicius, R. Sidaraviciute et al., "Characterization of particulate and vapor phase polycyclic aromatic hydrocarbons in indoor and outdoor air of primary schools," Atmospheric Environment, vol. 82, pp. 298-306, 2013.

[46] S. Kong, X. Ding, Z. Bai et al., "A seasonal study of polycyclic aromatic hydrocarbons in $\mathrm{PM} 2.5$ and $\mathrm{PM}_{2.5-10}$ in five typical cities of Liaoning Province, China," Journal of Hazardous Materials, vol. 183, no. 1-3, pp. 70-80, 2010. 

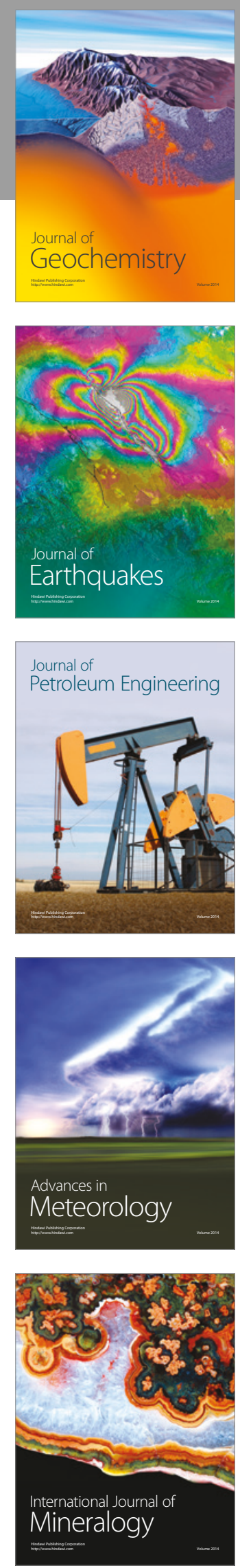
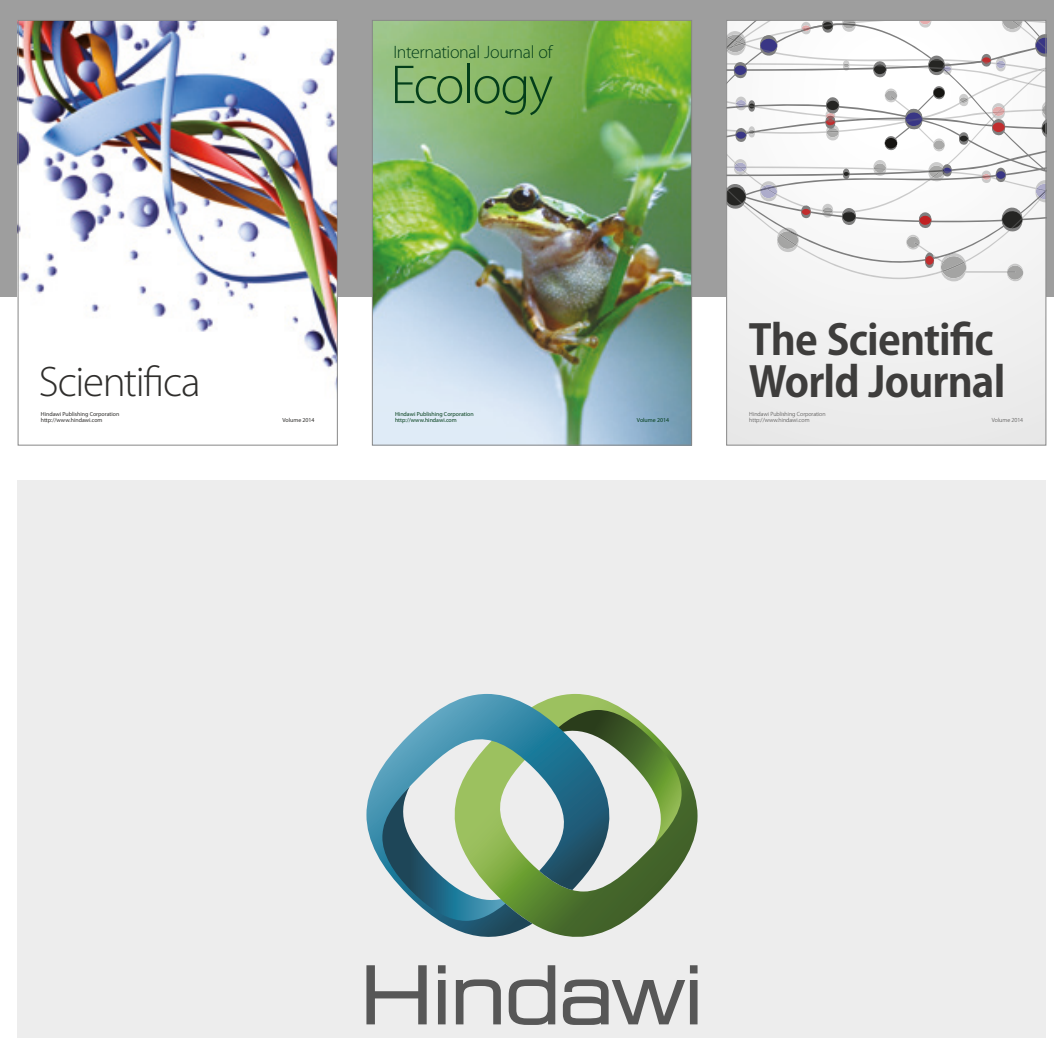

Submit your manuscripts at

https://www.hindawi.com
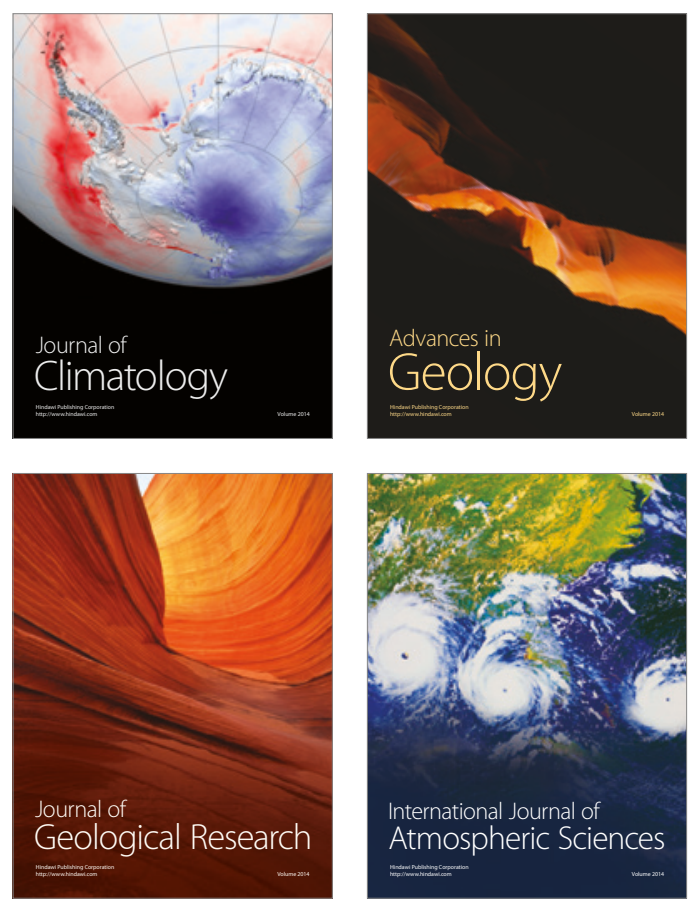

The Scientific

World Journal
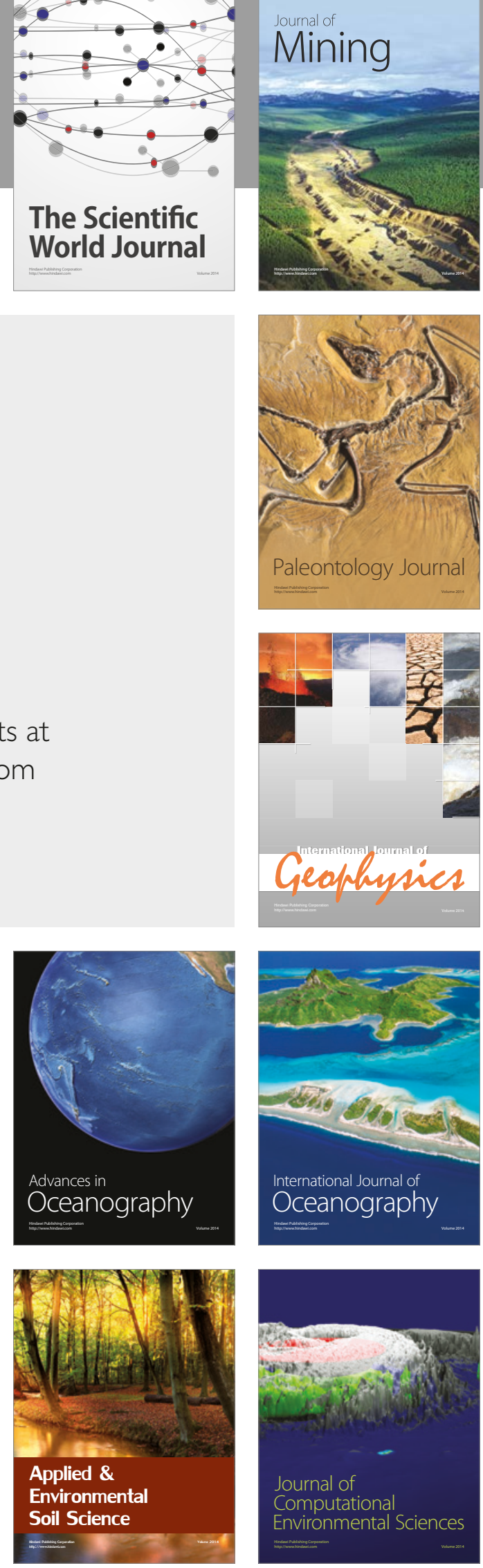